\title{
East Asia: \\ The Systemic Disorder and the South China Sea' Dispute. An International Law Prospect
}

\author{
Victor Alexandre G. TEIXEIRA \\ José Francisco Lynce Zagallo PAVIA
}

\begin{abstract}
This paper analyzes the South China Sea dispute when the international system lacks orientation and respect for the norms, values, and institutions. The conflict is conceptualized to encompass the States, International Law, and the East Asia order. The evidence demonstrates that ASEAN's regional order is more efficient than the US-Led Liberal order through UNCLOS. Additionally, it is necessary to overhaul and strengthen the institutional mechanisms from international Law regarding the United Nations. A change in the order and an international recognition are recommended to legitimize regional institutions to arbitrate territorial disputes.
\end{abstract}

Keywords: ASEAN; Regional Order; Conflict Resolution; South China Sea Dispute.

The international system continues to exhibit changes and diffusion of power, which have created a complex structure of different orders and different domains (Johnston, 2019). China's rise is the target for this change, but power in global politics is no longer related to polarization. The establishment of a nonpolarity world is rooted in a systemic change, together with the creation of distinct East Asian orders due to the China's rapid technology and economic development. The effect was a regional development network reshaped to interconnect
Victor Alexandre G. TEIXEIRA

Postdoctoral Fellow,

Department of International Relations,

Faculty of Political Science,

Chulalongkorn University, Thailand.

E-mail: victorale@zoho.com

José Francisco Lynce Zagallo PAVIA

Associate Professor,

Lusíada Universities Lisboa, Portugal.

Director of Lusíada Research Center

on International Politics and Security

E-mail: pavia.jose@gmail.com

Conflict Studies Quarterly

Issue 34, January 2021, pp. 66-83

DOI: $10.24193 / \mathrm{csq} .34 .4$

Published First Online: 05 January /2021 
factories and products, increasing exports and imports in many East Asian countries. Additionally, China drives for a domestic consumer market and its efforts to create a more ambitious regional network with the construction of numerous projects, increasing production and exports through the belt and road initiative.

Simultaneously, we witness the involvement of Asian countries in regional institutions, leading to a departure from the US-led liberal order, in particular when it is to decide or resolve regional issues. Concerning the dispute in South China Sea it seems that claimant's preference is ASEAN (Fravel, 2011). In the initial stages, China's position concerning the South China Sea was for delay strategy. Recently, China gradually shifted towards escalatory strategies but has mostly refrained from them and concentrated more on consolidating its position in the region (Roberts, 2018). Regardless of this, the dispute is China's heart sovereignty interest.

Sovereignty means the exclusive right and power of the governing body on itself, without any interference from the outside bodies. As defined by the Concise Oxford Dictionary, Sovereignty is the absolute authority of a State or nation to exercise governance by itself. Thus, when the State fails to do so, we can consider that we are in the presence of a "Failed State" (Pavia, 2017). Sovereignty incorporates rights and thereby ownership or title over a property. The South China Sea conflicts arise from competing for sovereignty claims by several states in the region, primarily by China, and countering these claims by the rival states with backing from the US.

With its vast yet largely unexplored resource potential, the strategically-located South China Sea is, understandably, a prize enticing many claimants under the guise of sovereignty (Cheeppensook, 2020). Over the past four decades, the competing states have not resorted to military action to settle any dispute due to the 'ASEAN Way' of using the concept and practice of consultation and consensus. This traditional Javanese approach may work in the 21st century, where the stakes in the region are high. The region enjoyed peace because the United States has enforced the freedom of navigation under the United Nations Convention on the Law of the Seas (UNCLOS) of 1982.

This instrument gave rise to several issues. This article uses it as a foundation and framework to analyze China's sovereignty claims in the region, its rejection of the Arbitral Chamber's jurisdiction and Award, indicating it is above the rule of law. The Convention's grant of freedom of navigation has been used by the US, a non-signatory state, and reliance thereon by former President Obama's Administration to maintain harmonious relations in the region.

\section{The UNCLOS authority decline}

China's started to claim South China Sea during the Han dynasty (206 BC to 220 AD) and through the ocean's use by fishers and merchants (Pham, 2010). Additionally, Imperial China's first official claim dates from a treaty with France on the Gulf of Tonkin in 1887 
(Pham, 2010). China considered this area to incorporate the South China Sea based on its "nine-dash line" delineation. EU asserted that China marked its territorial claim using the so-called "nine-dash line," as first depicted by a Chinese cartographer on a map published in December 1914 and gradually adopted by Nationalist China (Er, 2016).

This demarcation incorporates 90 percent of the South China Sea, an area of approximately 150,000 square miles. Later on, the Republic of China proposed the nine-dash line in 1947 and later on validated by the People's Republic of China (PRC). The Chinese Maps, which were submitted to the UN, claimed that their territory included almost the entire South China Sea (Baumert \& Melchior, 2014).

The requisite provisions for an analysis of disputes in the South China Sea are outlined in the 1982 United Nations Convention of the Law of the Seas (UNCLOS), signed on December 10, 1984 (Joshi, 2016). Under General Provisions in Section 1, Article 2 prescribes the following:

1. The sovereignty of a coastal State extends, beyond its land territory and internal waters and, in the case of an archipelagic State, its archipelagic waters, to an adjacent belt of sea, described as the territorial sea (EUR Lex, 1998, p. 1).

2. This sovereignty extends to the air space over the territorial sea as well as to its bed and subsoil (EUR Lex, 1998, p. 1).

3. The sovereignty over the territorial sea is exercised subject to this Convention and to other rules of international law (EUR Lex, 1998, p.1).

Article 3 puts a limit on any territorial sea's breadth to 12 nautical miles right from the prescribed baseline. Article 15 provides that such demarcation would not apply where, because of "historical title", it may not be necessary to limit the territorial sea. The UNCLOS does not define historical title. Hence, China's claim over its sovereignty regarding the enclosed area by its "nine-dash line" perimeter cannot be decided firmly under the circumstances (Hughes \& dos Santos, 2016).

Potential conflicts are bound to arise when any claim based on sovereignty leads to proclaiming an exclusive economic zone (EEZ), prescribed in Article 5 of the UNCLOS. This treaty limits the perimeter of an EEZ to 200 nautical miles from a country's coastal baseline. With several ASEAN members proclaiming their respective EEZs in the South China Sea, overlapping of "ownership" is inevitable, with some dubious claims capable of being disputed. This issue is addressed by reviewing the relevant articles of the UNCLOS (Keyuan, 2006). China is a signatory to the Convention, whereas the US is not. Contrarily, according to a former US diplomat, Chas W. Freeman Jr. the "South China Sea was a regional commons before the emergence of nation-states, with fisherfolk and seafarers using the sea for thousands of years without going into the issue of ownership of the largely uninhabited islands" (Joshi, 2016, p. 3). 
The sovereignty claims of China over the South China Sea precedes the UNCLOS. Plus, given the South China Sea's strategic location and resources, many other nations have a keen interest in the region's developments. The US's foreign policies and strategies on Southeast Asia that are primarily based on freedom of navigation have contributed to the maintenance of peace in the area. US threat awareness breakwater after the US navy surveillance team's coercion by the Chinese Ships in the SCS in March 2009. Recently, the US ships' military operations were close to a confrontation with a Chinese destroyer in the South China Sea waters when the two vessels came within 41 metres of each other had raked up tensions between China in September 2018.

However, in the face of increased Chinese military activity, this includes naval maneuvers and exercises, as well as the construction of industrial outposts, ports, military installations, and airstrips on artificial land, particularly on Paracel Island and Spratly Island, a more aggressive reaction would be expected from the claimants' states of SCS. Furthermore, China has militarized Woody Island on which it constructed a radar system and from where it deploys fighter jets and cruise missiles (BBC, 2016). Such actions constitute the practical implementation of the new policy adopted in China regarding foreign relations, which incorporates its stance on the South China Sea.

Furthermore, China unilaterally proclaimed an Air Defense Identification Zone (ADIZ) over the East China Sea in November 2013. This decree demands that any aircraft flying within the 130-kilometer ADIZ must:

"Report a flight plan to the Chinese government, maintain radio communication and respond to identification inquiries from the Chinese government, maintain radar transponder function, and exhibit clear nationality and logo markings" (China's Defense Ministry 2013, as cited in Osawa, 2013, p.1).

The ADIZ covers over two-thirds of the area. The absence of any consultation has resulted in much overlap with other countries' ADIZs (Fravel, 2011, 2016). Objections have been raised by China's neighbors, Japan, South Korea, and the US. Many observers of the international scenario have asserted that China has sufficient capabilities to conduct 24 hours surveillance in the maritime as well as through the air around the South China Sea; it may establish an ADIZ there. They added that following several dangerous near missions in 2013, and in 2014; the two sides, the US and Chinese forces, made a treaty that determined the expected code of conduct on naval ships. However, the risk of a dangerous incident between these states within China's EEZ is still a major concern due to the possibility that there could be a military escalation. Keeping in consideration, these activities by China, the US has increased its naval presence and military activity in the South China Sea based on freedom of navigation guaranteed by the UNCLOS (Hong, 2013). 
The freedom of navigation essentially pertains to Article 86 under Part VII of Section 1 describes "high seas" as all parts of the sea that are not included in the exclusive economic zone, in the territorial sea or in the internal waters of a State, or in the archipelagic waters of an archipelagic State (Hong, 2013). Article 87 provides that the "high seas are open to all States" and that "freedom of the high seas is exercised under the conditions laid down by this Convention and by other rules of international law" (United Nations part VII, art. 87). The Sections 1(a)-(f) allow all States to have the right to navigation, overflight, laying of submarine cables and pipelines, construction of artificial islands and other installations, fishing, and scientific research.

\section{Cluttered order in the South China Sea}

The US motive for its activities in the region is to protect its own economic, military, and political interests, including support to its allies in the area. The US conducted six freedoms of navigation operations in the South China Sea between May and August 2018. In his visit to East Asia in November 2017, President Donald Trump highlighted the importance of such operations (Cheeppensook, 2020). In 2017, Japan, one of the US allies, sold military ships and equipment to the Philippines and Vietnam to increase security capacity and counter Chinese "assertion" (Lindgren \& Lindgren, 2017). Furthermore, China argues that in terms of the UNCLOS, foreign powers are precluded from conducting intelligence-gathering activities, including reconnaissance flights, in or over its EEZ.

Earlier, in July 2016, the Permanent Court of Arbitration (PCA) in The Hague in PCA Case No. 213-19 (The Republic of the Philippines vs. The People's Republic of China) declared its award (Cogliati-Bantz, 2016). The tribunal ruled in favor of the Philippines as well as shed light on the issues and problems inherent in provisions of the UNCLOS 9 (CogliatiBantz, 2016). China did not appear at the hearing, so the tribunal made what was the equivalent of a "default judgment" in terms of Article 9 under Annex VII of UNCLOS ("Default of appearance"). China claimed that its refusal to participate in the arbitration was based on the policy that requires it to resolve "disputes had to be only settled by negotiation and agreed between the parties"(Cogliati-Bantz, 2016, pp. 761-762). The tribunal ruled that China's historical sovereignty claim based on the "nine-dash line" is inconsistent with the maritime zones proclaimed by UNCLOS (Beckman, 2013). China rejected both the standing and authority of the tribunal to hear the dispute and its ruling. Despite China being a signatory of the UNCLOS, its rejection of the tribunal's rulings and the awards an infringement of the sea law. On July 13, 2016, President Xi Jinping stated that the tribunal's judgment would not have an effect on the maritime activities in the South China Sea (Ikenberry, 2015). Since UNCLOS as an authority lacks the requisite power of enforcement, China could carry on as before (Ikenberry, 2015). This makes the situation precarious for the future conduct of claimants in the South China Sea dispute. However, the award was not without defects. The situation, coupled 
with China's "assertive" policy on the region, has the potential for conflict in the region that could have negative global impacts (Guan, 2000).

No severe conflict has occurred to date, even though the tensions have risen in the South China Sea since 2009; however, this could be the proverbial lull before the storm keeping in view the belligerent and unconsciousness of President Trump's statements that the US is above the law. The same is true for China, considering its rejection of the Arbitral Chamber's jurisdiction and award (Shicun, 2013). Accordingly, it has also begun implementing its new foreign policy aggressively with complete disregard of the UNCLOS.

The Chinese claim to vague "historic rights" within the so-called "nine-dash line" (NDL) is making the process of dispute resolution a complex affair. In the first instance, the NDL was fronted by the Republic of China in 1947 and later recognized by the PRC (Hayton \& Torode, 2014). Chinese officials have declined to express the extent of the rights within this line after the map that was presented by NDL, showing Chinese covering the entire line. UNCLOS does not allow the kind of claims that China is making about the meaning of NDL (Hayton \& Torode, 2014).

Historically, the region is particularly sensitive militarily for China as it has a crucial submarine base on Hainan Island from where its vessels move through the South China Sea waters. There have been few clashes incidents over the past few years, such as in 1988 on Johnson Reef, in 1994-1995 on Mischief Reef (Shicun \& Huaifeng, 2003). After this assault, resentment increased over China's conduct and intentions in the South China Sea region. In a diplomatic attempt, China signed a regional nonbinding Declaration of Conduct in November 2002 with member states of ASEAN (Shicun \& Huaifeng, 2003). This implied a voluntary restraint, negotiation, and consultation rather than conflict to resolve disputes. However, the Declaration of Conduct for diplomatic negotiations to offer a solution to the dispute without necessarily engaging in active confrontations with the military. However, this did not deter the continued conflicts between the two nations over the US Navy activities in the EEZ of China's territorial waters (Shicun \& Huaifeng, 2003). During the last few years, the Southeast Asian claimants have tried to present a unifeid front as ASEAN in order to find a solution. Instead, the US government has voiced Chinese actions as provocative, aggressive, and destabilizing in a series of statements.

International politics have been witnessing time and again to the instances where countries have failed to identify a present danger or simply not reacted to it, or reacted in a trivial manner. International politics have been witnessing time and again when countries have failed to identify a present danger or not react to it or react trivially. This behavior can be termed 'under-balancing' works contrary to the assumption that threatened states will balance by building alliances or by increasing military capacity or both. In this context, no competitor emerged for more than a few decades after the end of the US-Soviet Cold War to balance out the United States. If this is the case, the term 
should be an overbalancing, which occurs when a state incorrectly perceives another nation as threatening (Schweller, 2004).

The Permanent Court of Arbitration (PCA) makes a ruling on the South China Sea dispute, which was useful as reference precedence in determining such related issues regarding the Exclusive Economic Zone (EEZ) as well as territorial waters (De Castro, 2017). However, China asserts that its territorial sovereignty and maritime rights would not be affected by the ruling, which declared large territorial waters as neutral or EEZ of other countries. China keeps running naval exercises in the disputed waters. To reduce the tension and manage conflict, ASEAN countries and China have been conducting talks for more than a decade (De Castro, 2017). Though the ASEAN is united on the Code of Conduct (COC) but China insists on terms that any code should not interfere with its naval patrols. The idea of COC took shape in the 1990s but was formally mandated only by 2002 at a meeting of foreign ministers of ASEAN and China. However, little progress has come while the tensions have escalated. On August 3 of 2018, the foreign ministers who constituted the ten member states of the Association of Southeast Asian Nations (ASEAN) with the Chinese people make a pronouncement on the Single Draft South China Sea Code of Conduct Negotiating Text (SDNT) that served the foundation leading to the adoption of the South China Sea (Storey, 2017; Thayer, 2018; Zou, 2020).

\section{The US role in the South China Sea}

The US policies have contributed significantly to fostering American growth for more than three decades. The US military dominance, military presence, and related actions have diminished the possibility of escalating conflict in the past few decades, resulting in the realization of Asian economic emergence (Sinaga, 2015). However, the marine territorial disputes in the South China Sea are a constant hindrance to the US interests, and the situation becomes precarious as it exhibits the rise of China and its increased interests in the region. Since each country is bound to expand and progress, the increase in China's interest is natural.

The UNCLOS states the seas as an area of freedom, which is critical to the US as a global power. The US has to ensure that the area is not declared as an Air Defense Identification Zone to maintain freedom of overflight (Xie \& Shan, 2012). All the nations in the Asian Pacific regions, which encompassed China, have a common interest in the trade and commerce route that this area provides; it is necessary to prevent any interference. The US-led liberal order already shows signals of his incapacity to unravel global problems. The US still operates under military options to fix issues and achieve national interests, and interventions only make situations worse. Recently, the system's lack of authority along the US' predominance led to interventions in Libya, Iraq, and Afghanistan, and none of those was a success (Drezner, Krebs, \& Shweller, 2020)Surprisingly, after the 
international system establishment in October 1945, only the Kuwait intervention could be called a success.

However, according to the US, its most crucial objective is the peaceful resolution of the dispute and restrainment from coercion as it is critical for regional stability and peace. Structural necessities do not compel the political leaders to adopt one policy overriding another; however, this does not mean ignoring such necessities. Preferably, the response to threats and opportunities is calibrated by giving due consideration to policymakers who reach a consensus within the competitive political systems.

Recent face-offs between the US and China in the international waters have shown a disregard from the military powers' part for international laws. The tendency is common to both nations. While the US starts such actions, other nations generally follow in such infringement's activities. The US has often rejected the jurisdiction of international tribunals in recent decades. The US refused to ratify the 1982 UNCLOS agreement (Zhang, 2015). The immense claim made regarding the South China Sea is the NDL, which covers nearly the entire South China Sea (Zhang, 2015). China has clarified the nine-dash line, which is the contest that it makes in that it owns the marine area and all the creatures in that locality. This is a serious claim that would have an immense effect on the other States' rights and probably destabilize the current living state (Zhang, 2015). However, we must note that neither China nor any other country lays claim to the entire South China Sea (Hong, 2012). Officially, China claims the South China Sea Islands Dongsha/ Pratas Islands; Xisha/Paracel Islands; Zhongsha Islands, and Nansha/Spratly Islands with their adjacent waters and asserts based on "historic rights" within the "nine-dash line" (Government of the People's Republic of China, 2014).

Trump's rejection of the ruling of the International Court of Justice in 2018 points to the US considering itself above the rule of law, a dangerous precedent that could persuade other states to do the same, as done by China in 2016. Dehghan and Borger (2018) reported that the ICJ in a unanimous decision on October 3, 2018, "reprimanded the US over its re-imposition of sanctions on Iran, ordering Washington to lift restrictive measures linked to humanitarian trade, food, medicine, and civil aviation" (pp. 1-2). This was a victory for Iran after it "complained to the ICJ in July that the return to sanctions imposed by Donald Trump following the US withdrawal from the 2015 landmark nuclear agreement was in violation of theTreaty of Amity, a 1955 pre-revolutionary friendship treaty" (Dehghan \& Borger, 2018, p. 1-2). Without an analysis of the judgment, Secretary of State Mike Pompeo declared that the US would ignore the court's ruling: "I am disappointed the court failed to recognize its lack of jurisdiction" (Dehghan \& Borger, 2018, pp. 1-2).

Ignoring the ICJ's ruling bodes ill for international relations and cooperation. The Speech that was made to the UN General Assembly on September 25, 2018, President Trump 
said, "We reject the ideology of globalism and accept the doctrine of patriotism" (Borger, 2018; pp. 1-2). Throughout his speech, he defended "America's sovereignty". Much of his second address repeated what he had said in his first. He boasted about the "America First" world view, was concerned of the national security issues including nuclear talks with North Korea following his fiery speech the previous year when he vowed to "totally destroy" it issuing threats to the US and its allies; coercion with Iran; and his trade rivarly with China (Borger, 2018).

\section{China's role in the South China Sea}

The South China Sea is a priority in China's foreign policy due to its political, economic, and geographical location. China's policy towards this is mainly to divide and conquer. It encourages the ASEAN countries who do not dispute with China to remain on the sidelines while bilaterally handling those with the dispute to keep the US out of the South China Sea. A typical policy regarding Power Politics and every global actor in China's position probably chose the same approach.

China limits Japanese autos' import to display its disapproval of Japanese policies (Amy Searight, 2017, cited in Roberts, 2017). China lets Philippines produce spoil on the wharf to show disapproval of Manila opposing China's policies on the South China Sea. Most of the nations have made the argument that China should agree to the UN convention, UNCLOS, which is the organ that is supposed to set maritime zones of control along the coastlines (Amy Searight, 2017, cited in Roberts, 2017). The US is one such country that agrees with UNCLOS's resolution and is commonly known to abide by this body's resolutions. However, China borrows from the temporal laws that are founded on historical records and evidence from archeological findings from the Islands to claim territorial boundaries. China has consistently stated that the UN codes on maritime governance are incompatible with its region, arguing that it is a Western-based organ to influence regional agendas and oppress the Chinese rise as a superpower (Amy Searight, 2017, cited in Roberts, 2017).

Naturally, China initiates a massive institutional program focusing on creating regional economic institutions promoting a departure from UNCLOS by inciting mechanized processes to negotiate and find solutions within the regional institution, ASEAN (Teixeira, 2019; Xie \& Shan, 2012). It has set up and encouraged China-led the Asian Infrastructure Investment Bank to support the belt and road initiative, providing special privileges to a nation that supports it in the United Nations, and offers loans to nations which are more than the total of those given by the World Bank and the International Monetary Fund (Amy Searight, 2017, cited in Roberts, 2017). The rise of China has intensely impacted the regional economy and strengthened the relationships between East Asia countries. It all starts with East Asian' nations disappointment with the Western disregard during the Asian-based financial crisis experienced in East Asia in 1997. 
In 2002 , the summit consented to the declaration on conduct in the SCS, which formally commits Claimants to enforce nonaggression principles, particularly noninterference (Shambaugh, 2005). With biannual summits meetings, the institution provided China's (and other members) the perfect platform to successfully ouster US-led institutions over the Asian ones. Over time, China shifted toward noncompliance with UNCLOS, and regional political mechanisms and social processes were noticeable by escalatory dynamics. Indeed, even if China is a UNCLOS member, it has officially subscribed to a different framework for the resolution of the dispute (Shambaugh, 2005).

The Chinese Society of International Law conducted a significant case study titled The South China Sea Arbitration Awards: A Critical Study, to shed light regarding the opinion of the Chinese government concerning the awards in favor of the Philippines on October 29, 2015, and July 12, 2016, in the South China Sea territorial arbitration (CSIL, 2018). In it, the institution raises several vital aspects that would make the awards a violation of China's autonomy and territorial integrity, and international law (CSIL, 2018).

First, the study raises questions over the jurisdiction of the tribunal and admissibility of the Philippines' evidence.The Philippines presented submissions relating to territorial and maritime delimitation disputes with China over the South China Sea. The Philippines contends that China's nine-dash line claim is null and void because it goes against UNCLOS provisions on exclusive economic zones and sea territory. This is because most of the Spratly Islands, which it claims cannot sustain life and cannot stand as an independent continental shelf as per the UNCLOS convention. China declined participation in the arbitration because it has treaties with the Philippines and the ASEAN (to which the Philippines belong) prioritizes bilateral negotiations in disputes of this nature (Zhao, 2018). It further issued a white paper in 2014 arguing its position by terming the dispute as relating to sovereignty and not falling under arbitration courts. In response, the tribunal declared it had jurisdiction over the issue and declared the Philippines' evidence as admissible in the hearings in October 2015 before ruling in favor of the latter in July 2016 (Zhao, 2018).

The case study further points out the deficiency in the ruling that China has no historical rights in the South China Sea by highlighting the separation of this aspect from territorial and maritime delimitation, which was pending as a bilateral dispute between China and the Philippines. Since this dispute is still unresolved between the two countries, the rationale for effecting Article 56, 57, 62, and 77 of the UNCLOS convention does not exist (Zhao, 2018). This is more proof of the tribunal having an ulterior motive against China.

Third, the case study points out that the tribunal's ruling on the status of China's Nansha Qundao and Zhingsha Qundao is flawed because it addresses each island separately, yet they form part of the same archipelago; effectively dismembering them to facilitate ruling against China. International law ably addresses these archipelagos' status, and 
the tribunal erred in assuming jurisdiction over something, then misinterpreting the law and doing the country an injustice.

Fourth, the case study points out that by appropriating territories for the Philippines as belonging to its 'special economic zone and continental shelf, the tribunal was relying on pseudo-facts not founded on law and infringing on China's freedom to develop its territories in the SCS. In essence, the tribunal applied the convention on China and provided an exception for the Philippines in every scenario possible as a buildup to ruling in its favor. This sad state of affairs creates a bad precedent in the SCS because there are numerous disputes among the claimants, both at bilateral and ASEAN bloc level. This lopsided justice could open the doors to more unjust rulings from future tribunals against China and any other claimant who plays his politics selfishly. The case study correctly concludes that the ruling's deficiencies in favor of the Philippines deprive the awards of legitimacy and will definitely undercut the international rule of law, especially as regards territorial disputes and aspects of sovereignty.

In recent years, the different Chinese government has selectively and strategically used their domestic laws to create ambiguity of the Chinese claims' legal aspect, pit Chinese claims into context, and extend China's influence on the disputed area. The effect comes from the non-complianceof the policies, agencies and a challenge to the international laws itself. China has been able to use its domestic law to challenge international laws because its legal terminology does not cohort with international legal terminology. Hence, note verbale submitted to the UN in 2009 used words such as 'relevant waters' and adjacent waters, which are not defined in international law. This served as a foundation for altering the domestic maritime laws to remain ambiguous about the extent of China's boundaries in international waters.

China has been able to wield its geo-economics influence on institutions ranging from the UN General Assembly and ASEAN to IMF. It gives considerable confirmation that geoeconomic pressures work and succeed in advancing geopolitical interests that may or may not be positive. China has been able to influence the countries as well as institutions to alter their course in pursuing territorial interests. The level of geo-economic actions cannot be determined and cannot be assessed as happening or measured. However, when comparing the scant historical inventory available in such cases, it can be significantly said that the geo-economic efforts are rising (Scobell, 2017).

Like military power, geo-economic measures too can cause a sway of influence. At times, geo-economic success is often exaggerated, especially in the case of China. Their internal obligations and natural limits that do not allow the application of unlimited geo-economic pressure. China can have domestic issues such as the social welfare system, stock market issues, housing problems, and government corruption. Similar to any other country, there can be a clash between geopolitical interests and purely economical interests. 
The participants, at times, can be less than willing to be perturbed by geopolitical needs. A pressure that may seem undue can force the Southeast Asian countries to achieve a measure of balance by inching closer to the US (Kumari, 2014). The geo-economic pressure can prove to be more effective when obliquely implied rather than directly imposed. At times, China's attempt to exercise geo-economic pressure heavy-handedly along with assertive marine actions in the South China Sea did not have the desired results. Nevertheless, China's geo-economics prowess has had more than a substantial positive effect.

Realizing that nationalism is very eminent in Chinese society, the Chinese leadership placed it alongside patriotism and pride as the government's fundamental tenets (Sinaga, 2015). Emboldened by such decisions, China actively began engaging in war, like activities that encompassed military force in the South China Sea to toughen its claims therein (Sinaga, 2015).

\section{The ASEAN and the Social Compact}

Yaqing Qin (2014)asserted that the "sovereignty competition" experienced among the Chinese neighbors regarding territorial borders and resources in the South Sea China could continue despite being there for more than four-decade (Qin, 2014). This conflict has attracted international diplomats' attention, including military organizations devoted to promoting stability and peace across the globe. No provision in the UNCLOS allows China to interrupt the independence of triangulation or act as a sole regulator of the South China Sea (Teixeira, 2018; Beckerman, 2013). Notwithstanding these provisions and given that both the US and China have not accepted the rule of law, under the guise of innocent passage, the US could carry out reconnaissance activities that would culminate with challenging China on the assumption that it acts against the US by violating its freedom to navigate (Teixeira, 2018).

The Convention, however, provides for freedom of navigation but does not guarantee it. Hence, under the pretext of "innocent passage", a country like the US could carry out covert setups in the South China Sea, and so could China. Given China's national priorities and the insistent international policy being implemented proactively, it does not help to give its stance a theoretical label like "revisionist". Indeed, China's contestation may be anti-order, but also shows signs that can be pro-order (Goh, 2019).

Furthermore, in August 2018, a Single Draft South China Sea Code of Conduct Negotiating Text (SDNT) will form the ground for the endorsement of the code of conduct in the South China Sea. All countries contributed to the document, with the most notable being China's view regarding cooperation and the marines States, which was to be expedited along with littoral States "and shall not be conducted in cooperation with companies from countries outside the region" (Thayer, 2018, pp.1-2). In contrast, Malaysia anticipated that nothing in the COC "shall affect... rights or ability of the Parties to conduct 
activities with foreign countries or private entities of their own choosing" (Thayer, 2018, pp. 1-2).

China notes that in the first point "military activities in the region shall be conducive to enhancing mutual trust" (Thayer, 2018, p. 1). China's second point calls for an exchange and relation regarding the defense and military forces including "mutual port calls of military vessels and joint patrols on a regular basis. Point three calls for undertaking joint military exercises among China and ASEAN Member States on a regular basis" (Thayer, 2018, p. 2).

China's fourth point states that Parties involved, shall establish a notification mechanism regarding military activities and make proper communication if there is a need for military incursion when deemed necessary. The Parties will not hold joint military activities with nations outside the region, except if the gatherings concerned are advised previously and express no complaint. China's fifth point takes note of that military vessels and airplane appreciate sovereign invulnerability and are "immune from the jurisdiction of any State other than the flag state. Further, military vessels and aircraft are entitled to self-defense, but should have due regard for the other side's military vessels and military aircraft. China and the Philippines both inserted point six that called for the just and humane treatment of all persons who are either in danger or in distress in the South China Sea. Finally, the Philippines proposed point seven that included respect of the exercise of traditional fishing rights by fishermen... access to features and fishing grounds" (Thayer, 2018, p. 3).

We can testify that ASEAN is on the right path; it produces the necessary cooperation to reach a resolution. At least its decision-making processes are not rejected but negotiated. The process in which an institution with regional consent to establish order and authority will determine an explicit social conception of regional order centered on cooperative negotiations of shared perceived values, norms, and duties between them, resulting in a social compact (Adams, 1842; Gilpin, 1981).

A compact illustrate the mutual and conditional exchange of commitment: to a regional member is provided some privileges by others in return for certain constrains, benefits, duties or provide development that uphold the region and its members. A similar situation is underway in Europe; the European Union is taking the lead and we witnessed more and more of an "Europeanisation of Maritime Issues" (Pavia, 2019, p. 131).

\section{Conclusion}

From the evidence, we can consider that ASEAN has the determining structural mechanism to resolve the dispute. The institution is marked not only by superior capability but also by his members' support. Namely, it has regional legitimacy derived through negotiation between members than by imposition. The most probable situation for the 
eventual fate of the SCS questions is the support of the norm, where talks are saved casually and concentrated on specialized issues. One could contend that this circumstance is passable, in any event for the time being, and that the petitioners may keep on fulfilling their household populace by comments and explanations yet will stay away from outfitted clash because political and monetary costs included. This includes living with business as usual until there were diminished pressures and the probability of political chiefs settling that no nation has an ideal case in the SCS. Thus, they have to bargain for the opportunity of a set of accepted rules to be figured out.

Furthermore, over the last 20 years, diplomatic relations between China and the US have significantly improved and saved the few instances that could derail the US's relationship until recently where the trade rivalry has arisen (Wang, 2010). The last five US administrations have attempted to demonstrate an impartial position regarding the South China Sea dispute by resorting to a softer non-coercive approach entangled in the territorial dispute. The senior US administration officials' approach does not depict that the US will remain neutral in the South China Sea disputes and needs to resolve them without coercion (Liff \& Erickson, 2013). However, this effort, which appears unbiased, is problematic to maintain, since the US appears to depict many states in the South China Sea dispute into its politically based process that relates to military force, excluding China from any participation.

\section{References}

1. Adams, J. Q. (1842). The social compact: exemplified in the Constitution of the commonwealth of Massachusetts : with remarks on the theories of divine right of Hobbes and of Filmer, and the counter theories of Sidney, Locke, Montesquieu, and Rousseau, concerning the origin and nature of government. Providence: Knowles and Vose.

2. BBC. (2016, July 12). Why is the South China Sea contentious?. BBC World News. Retrieved from https://www.bbc.com/news/world-asia-pacific-13748349.

3. Beckman, R. (2013). The UN Convention on the Law of the Sea and the maritime disputes in the South China Sea. American Journal of International Law, 107(1); 142-163. DOI:10.5305/amerjintelaw.107.1.0142.

4. Baumert, K., \& Melchior, B. (2014). Limits in the seas, No. 143, China: Maritime claims in the South China Sea. Washington: Office of Ocean and Polar Affairs, Bureau of Oceans and International Environmental and Scientific Affairs, US Department of State.

5. Borger, J. (2018, September 26). Trump urges world to reject globalism in UN speech that draws mocking laughter. The Guardian. Retrieved from https://www.theguard ian.com/us-news/2018/sep/25/trump-united-nations-general-assembly-speech-glo balism-america.

6. Cheeppensook, K. (2020). ASEAN in the South China Sea conflict, 2012-2018: A lesson in conflict transformation from normative power Europe. International Economics and Economic Policy, 17(3), 747-764. DOI:10.1007/s10368-020-00477-z. 
7. Chinese Society of International Law. (2018). The South China Sea Arbitration Awards: A Critical Study. Chinese Journal of International Law, 17(2), 207-748. DOI:10.1093/ chinesejil/jmy012.

8. Cogliati-Bantz, V. P. (2016). The South China Sea Arbitration (The Republic of the Philippines v. The People's Republic of China). The International Journal of Marine and Coastal Law, 31(4), 759-774. DOI:10.1163/15718085-12341421.

9. Drezner, D. W., Krebs, R. R., \& Schweller, R. (2020). The End of Grand Strategy America Must Think Small. Foreign Affairs, 99(3), 107-117. Retrieved from https://www.for eignaffairs.com/articles/world/2020-04-13/end-grand-strategy.

10. Dehghan, S. K., \& Borger, J. (2018, October 4). International Court of Justice Orders US to Lift New Iran Sanctions. The Guardian. Retrieved from https://www.the guardian. com/world/2018/oct/03/.

11. De Castro, R. C. (2017). The 12 July 2016 Permanent Court of Arbitration's (PCA) Award: The Philippines' Lawfare versus China's Realpolitik in the South China Sea Dispute. International Journal of China Studies, 8(3), 347-372.

12. Er, L. P. (2016). China, the United States, alliances, and war: avoiding the Thucydides trap?. AsianAffairs:AnAmerican Review,43(2),36-46.DOI: 10.1080/00927678.2016.1150765.

13. EUR Lex, European Union Law. (1998). "United Nations Convention on the Law of the Sea". Montego Bay Convention. Retrieved from http://data.europa.eu/eli/conven tion/1998/392/oj.

14. Fravel, M. T. (2011). China's strategy in the South China Sea. Contemporary Southeast Asia, 292-319. DOI: 10.1355/cs33-3b.

15. Fravel, T. (2016). US policy towards the disputes in the South China Sea since 1995. In E. Fels and T-M. Vu (eds.), Power politics in Asia's contested waters (pp. 389-402). New York: Springer. DOI.10.1007/978-3-319-26152-2_18.

16. Gilpin, R. (1981). War and change in world politics. Cambridge: Cambridge University Press. DOI:10.1017/cbo9780511664267.

17. Goh, E. (2019). Contesting Hegemonic Order: China in East Asia. Security Studies, 28(3), 614-644. DOI:10.1080/09636412.2019.1604989.

18. Government of the People's Republic of China (2014, December 7). Position paper on the Matter of Jurisdiction in the South China Sea Arbitration Initiated by the Republic of the Phillippines, Ministry of Foreign Affairs. Retrieved from https://www.fmprc.gov. cn/nanhai/eng/snhwtlcwj_1/t1368895.htm

19. Guan, A. C. (2000). The South China Sea Dispute Revisited. Australian Journal of International Affairs, 54(2), 201-215. D0I:10.1080/713613514.

20. Hayton, B., \& Torode, G. (2014). The South China Sea: The Struggle for Power in Asia. Contemporary Southeast Asia, 36(3), 467-469. D0I:10.1355/cs36-3f.

21. Hong L. (2012, February 29). Regular Press Conference. Retrieved from https://www. fmprc.gov.cn/mfa_eng/xwfw_665399/s2510_665401/2511_665403/t910855.shtml.

22. Hong, Z. (2013). The South China Sea dispute and China-ASEAN relations. Asian Affairs, 44(1), 27-43. DOI: 10.1080/03068374.2012.760785. 
23. Hughes, R. G., \& dos Santos, W. M. (2016). The Unquiet Frontier: rising rivals, vulnerable allies, and the crisis of American power. Intelligence and National Security, 32(2), 271-273. DOI:10.1080/02684527.2016.1246115.

24. Ikenberry, G. J. (2015). Between the eagle and the dragon: America, China, and middle state strategies in East Asia. Political Science Quarterly, 131(1), 9-43. DOI: 10.1002/ polq.12430.

25. Johnston, A. I. (2019). China in a World of Orders: Rethinking Compliance and Challenge in Beijing's International Relations. International Security, 44(2), 9-60.

26. Joshi, M. (2016). The South China Sea Disputes: Territorial Claims, Geopolitics, and International Law. Journal of Observer Research Foundationl. Retrieved from https:// www.orfonline.org/research/the-south-china-sea-disputes-territorial-claims-geopol itics-and-international-law/.

27. Keyuan, Z. (2006). Joint development in the South China Sea: a new approach. The International Journal of Marine and Coastal Law, 21(1), 83-109.

28. Kiogora, D. (2016). Vision of a Void: Shifting Global Power and the Future of U.S.-China Relations, SSRN Electronic Journal. DOI: 10.2139/ssrn.2779009.

29. Lanteigne, M. (2015). Chinese foreign policy: An introduction: Third edition. London: Routledge.

30. Liff, A. P., \& Erickson, A. (2013). Demystifying China's Defence Spending: Less Mysterious in the Aggregate. The China Quarterly, 216, 805-830.

31. MacDougall, J. C. (2017). Destined for War: Can America and China Escape Thucydides's Trap?. Parameters, 47(2), 113+.

32. Ngoei, W-Q. (2019). There and back again: What the Cold War for Southeast Asia can teach us about Sino-US competition in the region today. Canada's Journal of Global Policy Analysis, 74(2), 301-312. DOI:10.1177/0020702019855352.

33. Osawa J. (2013, December 17). China's ADIZ over the East China Sea: A “Great Wall in the Sky"?. Brookings. Retrieved from https://www.brookings.edu/opinions/chinasadiz-over-the-east-china-sea-a-great-wall-in-the-sky/.

34. Pavia, J. F. (2017). Estado Nacional e Novos Conflitos Armados. In L. Sousa, A. e Diz, J. Mata e Caldas and R. Gomes (eds), Contributo para o diálogo entre Direito Internacional e Relações Internacionais, ISCSP, UFMG e UNINOVE (pp. 145-156). Lisboa: Paz \& Guerra.

35. Pavia, J. F. (2019). The Europeanisation of Maritime issues and the extension of the platform shelves - National or European Resources? The case of Portugal. In J. F. Pavia and M. Monteiro (eds.), Estudos de Relações Internacionais (pp. 131-147). Lisboa: Universidade Lusíada Editora.

36. Pham, Q. M. (2010). The South China Sea security problem: towards regional cooperation. Asia Europe Journal, 8(3), 427-434. DOI: 10.1007/s10308-010-0283-6.

37. Qin, Y. (2014). Continuity through change: Background knowledge and China's international strategy. The Chinese Journal of International Politics, 7(3), 285-314. DOI: 10.1093/cjip/pou034.

38. Roberts, C. B. (2017, August 29). The South China Sea: Beijing's challenge to ASEAN and UNCLOS and the necessity of a new multi-tiered approach. RSIS. Retrieved from 
https://www.rsis.edu.sg/rsis-publication/rsis/wp307-the-south-china-sea-beijingschallenge-to-asean-and-unclos-and-the-necessity-of-a-new-multi-tiered-approach/\#. X4zqDS9h2qA.

39. Roberts, C. B. (2018). ASEAN, the "South China Sea" Arbitral Award, and the Code of Conduct: New Challenges, New Approaches. Asian Politics \& Policy, 10(2), 190-218.

40. Schweller, R. L. (2004). Unanswered Threats: A Neoclassical Realist Theory of Underbalancing. International Security, 29(2), 159-201.

41. Scobell, A. (2017). China in the Era of Xi Jinping: Domestic and Foreign Policy Challenges. Political Science Quarterly, 132(4), 759-760.

42. Shambaugh, D. (2005). China engages Asia: reshaping the regional order. International security, 29(3), 64-99.

43. Shicun, Wu., \& Huaifeng, R. (2003). More Than a Declaration: A Commentary on the Background and the Significance of the Declaration on the Conduct of the Parties in the South China Sea. Chinese Journal of International Law, 2(1), 311-319.

44. Shicun, Wu, (2013). Solving Disputes for Regional Cooperation and Development in the South China Sea: A Chinese Perspective, Solving Disputes for Regional Cooperation and Development in the South China Sea: A Chinese Perspective. Oxford: Chandos Publishing.

45. Sinaga, L. C. (2016). China's Assertive Foreign Policy in South China Sea Under Xi Jinping: Its Impact on United States and Australian Foreign Policy. Journal of ASEAN Studies, 3(2), 133-149.

46. Storey, I. (2017). Assessing the ASEAN-China framework for the code of conduct for the South China Sea. ISEAS Perspective, 62, 1-7.

47. Teixeira, V. A. G. (2018). China on Stage: Assumptions and strategies in South China Sea. Asian Journal of Social Science Studies, 3(3), 52-63.

48. Teixeira V. A. G. (2019). The United States' China containment strategy and the South China Sea dispute. Central European Journal of International and Security Studies, 13(3), 167-193.

49. Thayer, C. (2018). A closer look at the ASEAN-China single draft South China Sea Code of Conduct. The Diplomat, 3. 43-59.

50. UN General Assembly (1982, December 10). Convention on the Law of the Sea, Part VII, Section 1- General Provisions. United Nations. Retrieved from https://www.un.org/ depts/los/convention_agreements/texts/unclos/part7.htm.

51. Wang, D. (2010). China's trade relations with the United States in perspective. Journal of Current Chinese Affairs, 39(3), 165-210.

52. Xie, Y., \& Shan, W. (2012). China Struggles To Maintain Stability: Strengthening Its Public Security Apparatus. China, 55-62.

53. Yennie L., \& Lindgren, P. Y. (2017). Identity politics and the East China Sea: China as Japan's 'other'. Asian Politics \& Policy, 9(3), 378-401.

54. Zhang, Y. (2015). China and the struggle for legitimacy of a rising power. Chinese Journal of International Politics, 8(3), 301-322.

55. Zhao, S. (2018). China and the South China Sea Arbitration: Geopolitics Versus International Law. Journal of Contemporary China, 27(109), 1-15. 
56. Zou, K. (2020). Towards the Code of Conduct for the South China Sea: maritime security dimensions. In M. D. Evans and S. Galani (eds.), Maritime Security and the Law of the Sea (pp. 202-217). New York: Edward Elgar Publishing. 